\title{
Fatherhood in the Twenty-First Century
}

\author{
Natasha J. Cabrera, Catherine S. Tamis-LeMonda, Robert H. Bradley, \\ Sandra Hofferth, and Michael E. Lamb
}

\begin{abstract}
The twentieth century has been characterized by four important social trends that have fundamentally changed the social cultural context in which children develop: women's increased labor force participation, increased absence of nonresidential fathers in the lives of their children, increased involvement of fathers in intact families, and increased cultural diversity in the U.S.. In this essay, we discuss how these trends are changing the nature of father involvement and family life, and in turn affecting children's and fathers' developmental trajectories. We end with an eye toward the twenty-first century by examining how the children of today will construct their expectations about the roles of fathers and mothers as they become the parents of tomorrow. This life-span approach to fatherhood considers the broader sociohistorical context in which fatherhood develops, and emphasizes the urgent need to consider mothers, fathers, and family structure in future research as we seek to understand and model the effects of parenting on children's development.
\end{abstract}

\section{INTRODUCTION}

Social and historical contexts shape both popular and scholarly conceptions of children, families, and parenting, so it is important to view our contemporary understanding of family relationships in light of recent history. In the second half of the nineteenth century, fathers in the U.S. left their small farms and businesses to seek employment away from home in an emerging industrial economy. In so doing, they left the responsibility for rearing children largely to mothers, and, not surprisingly, the predominant construction of fatherhood in the twentieth century had at its core fathers' instrumental or breadwinning role in the family (LaRossa, 1997). The constant presence of mothers as children's primary caregivers fostered the implicit assumption that father-child relationships had little impact on children's development, and this popular belief was reinforced by developmental theorists throughout most of the century.

As we approach the end of the twentieth century, social changes are forcing adjustments in both popular and scholarly conceptualizations of fathers, mothers, and families. We have seen an evolution of father ideals from the colonial father, to the distant breadwinner, to the modern involved dad, to the father as coparent (Pleck \& Pleck, 1997). These ideals have been accompanied by four trends: women's increased labor force participation, the absence of many men from their families, the increased involvement of other fathers in children's lives, and increased cultural diversity in the United States. These trends demand that we reconceptualize American fatherhood and address such questions as: How will changes in the roles and expectations of mothers and fathers affect children's development in the new millennium? How will the boys and girls of today become the fathers and mothers of tomorrow? What type of intergenerational legacy will today's fathers and sons leave for those of the twenty-first century?

Our first goal in this essay is to address these questions in the context of our abbreviated analysis of the four important secular trends described here. Second, we discuss paternal influences on child development and anticipate the effects of societal change on these patterns of influence. Third, we articulate a contextualized life-span analysis, explaining how changes in the childhood experiences of boys and girls promise to alter their constructions of fatherhood and motherhood when they themselves become parents.

\section{THE CHANGING AMERICAN FAMILY}

Nothing has changed family life more in the twentieth century than the dramatic increase in mothers' labor force participation. Mothers have always been in the work force of course, but between 1830 and 1940, women were primarily involved in family businesses or worked in factories until they married. In 1950, $12 \%$ of married women with preschool children were in the work force and by 1997 that proportion had risen to two-thirds (U.S. Department of Labor, Bureau of Labor Statistics, 1986, 1997). As the rate of maternal labor force participation increased, so did enrollment of children in child facilities (Spain \& Bianchi, 1996). By 1995 there were almost 10 million children under 6 years old who were in nonparental care because their were mothers were employed (Hofferth, 1996). The

(C) 2000 by the Society for Research in Child Development, Inc. All rights reserved. 0009-3920/2000/7101-0015 
U.S. Department of Labor, Bureau of Labor Statistics (1997) projects that the largest job growth through 2006 will be in low-wage jobs which involve night and weekend shifts, jobs more often held by women. Younger workers with less seniority are likely to work these shifts and they are more likely than older workers to be rearing children. At the same time, the proportion of two-parent families in which fathers serve as the sole breadwinner has declined (Hernandez, 1993). Only about one-quarter of children live in such families today (Hofferth, 1998).

A second societal change that has dramatically altered the childrearing landscape is the heightened absence of fathers. In 1960, only 6\% of families in the United States were headed by females whereas $24 \%$ are so characterized today (U.S. Bureau of the Census, 1998). The proportion of children who live with only one parent at some time during their childhood years is expected to continue exceeding 50\% (Hernandez, 1993).

This increase in father absence is particularly troubling because it is consistently associated with poor school achievement, diminished involvement in the labor force, early childbearing, and heightened levels of risk-taking behavior (Federal Interagency Forum on Child and Family Statistics, 1998). Boys growing up without fathers seem especially prone to exhibit problems in the areas of sex-role and gender-identity development, school performance, psychosocial adjustment, and self-control (Hetherington \& StanleyHagan, 1986). Girls are affected by father absence too, although the effects on girls may be less enduring, dramatic, and consistent.

Most previous research on father absence has obscured individual differences in the patterning of effects in father-present versus father-absent groups. In the past two decades, however, many researchers have attempted to explain and explore within- as well as between-group differences (see Lamb, 1999, for reviews). There are five key ways paternal absence may influence children: (1) without a father there is no coparent; (2) economic loss frequently accompanies single motherhood (McLanahan \& Sandefur, 1994; Pearson \& Thoennes, 1988) and economic disadvantage is a reliable correlate of poorer educational and psychosocial performance; (3) social isolation and continuing (though diminished) social disapproval of single or divorced mothers and children may lead to emotional distress and less adaptive functioning (Hetherington, Cox, \& Cox, 1982; McLoyd, 1998); (4) the perceived, and often actual, abandonment by a parent may cause psychological distress in children (see Lamb, 1999; Thompson, 1986, for reviews); and (5) conflict between parents can have deleterious effects on children's socioemotional well-being and behavior (Amato, 1993; Cummings \& O’Reilly, 1997; Fincham, 1998).

For other families, paternal involvement, responsibility, and care have increased over the past three decades (Pleck, 1997; Yeung, Sandberg, Davis-Kean, \& Hofferth, 1999). Whereas fathers in intact two-parent families formerly spent about $30 \%$ to $45 \%$ as much time with their children as mothers did, they now spend $67 \%$ as much time as mothers on weekdays and $87 \%$ as much time on weekends (Yeung et al., 1999). These statistics do not reveal the reasons for, nor the quality of, this increased involvement; they might even reflect a decrease in the absolute amount of time mothers spend with children. The number of single fathers with children at home has also increased by $25 \%$ in the past three years from 1.7 million to 2.1 million in 1998. Men comprise one sixth of the nation's 11.9 million single parents (U.S. Bureau of the Census, 1999). This reflects an increased acceptance by courts and society of paternal custody, an increased tendency on the part of men to seek custody, and a greater willingness on the part of mothers and judges to agree. Although the overall number of such families remains small, they are noteworthy.

Although increases in the amount of time fathers spend with children may reflect changing conceptions of fatherhood on the part of American men and women (Pruett, 1987), they also appear to be sensitive to macro- and microeconomic circumstances. Specifically, increased rates of maternal employment, periods of economic decline, joint work schedules, flexible work hours, irregular work schedules, part-time employment, job sharing, and home-based work are all associated with increases in paternal responsibility for child care (Casper, 1997; Presser, 1995). The more mothers earn relative to their husbands, the more likely fathers are to care for their children, and husbands whose work hours differ from those of their wives are more likely to provide child care for their children (Brayfield, 1995; Casper \& O'Connell, 1998).

Lastly, high rates of immigration have led to marked changes in the racial and ethnic composition of the United States population. Between 1979 and 1989, the number of persons 5 years and older in the United States who were reported to speak a language other than English at home increased from 9\% to 12\% (see Hofferth, 1999a). Immigration, mostly from non-European countries, will account for half of the growth in the school-age population between 1990 and 2010 (Phillips \& Cabrera, 1996). This cultural diversity suggests different views of the appropriate roles and behaviors of fathers and mothers and challenges a universal conception of fatherhood. 
A cross-cultural understanding of fathers requires sensitivity to the function of men within families. For instance, although the father role is recognized in all cultures, responsibility for children may extend to men other than biological fathers, such as uncles and grandfathers (see Engle \& Breaux, 1998). Traditional conceptions of fatherhood in specific cultural contexts may also undergo change. For example, the view of the Mexican American family as characterized by an authoritarian male and a dependent, submissive female (Bozett \& Hanson, 1991) has changed in the face of urbanization and acculturation. An emergent model (Mirande, 1988) describes the family as more egalitarian and fathers as more nurturant than expected. Thus, roles of fathers and other men in children's lives will continue to evolve in the context of diverse cultural values and family ideologies.

Attempts to broaden the conceptualization of fatherhood have stimulated considerable debate among researchers, theorists, policymakers, and the public at large regarding the diversity of family types and parental roles (Tamis-LeMonda \& Cabrera, 1999). The ecology of family life is continuing to change and thus many children will grow up in the next century either without their biological fathers or with stepfathers. It is estimated that one third of children will spend some time in a nonmarital or stepfamily before they reach the age of 18 (Seltzer, 1994). Dissolutions of stepfamilies are also increasing (Bumpass, Sweet, \& Castro-Martin, 1990). This complicated family structuring will expose children to situations that demand adjustment to novel and complex relationships with sets of parents and siblings (Hetherington \& Henderson, 1997). Different father types will increasingly shape children's attachments, social-emotional competencies, linguistic and cognitive attainments, and orientation to family and work in the twenty-first century. Theoretical models of parenting must be reformulated to accommodate new family structures as well as culturally diverse conceptions of fatherhood.

\section{PATERNAL INFLUENCES ON CHILD DEVELOPMENT}

To best understand the effects of father involvement on children's development, it is critical to consider: (1) specific dimensions of father involvement, (2) children's outcomes, and (3) the pathways by which fathers influence their children.

Dimensions of father involvement. The single-minded focus on unitary dimensions of father involvement that dominated scholarship in the 1970s and 1980s has yielded to broader and more inclusive definitions (Lamb, in press; Palkovitz, 1997). For example, Lamb,
Pleck, Charnov, and Levine (1985, 1987) urged researchers to distinguish among accessibility, a father's presence and availability to the child, regardless of the actual interactions between father and child; engagement, a father's experience of direct contact, caregiving, and shared interactions with his child; and responsibility, a father's participation in such tasks as selecting a pediatrician and making appointments, selecting child care settings or babysitters, arranging after school care and the care of sick children, talking with teachers, and monitoring children's whereabouts and activities (Lamb, in press). Others have distinguished among the types of activities in which fathers and their children engage (e.g., play, direct care) or between the quantity and quality of care (Palkovitz, 1997; Parke, 1996).

Some researchers suggest that responsibility, which is often neglected in survey studies, may be the most important component of father involvement (Lamb, 1986, in press). For both resident and nonresident fathers, financial child support is an important form of paternal responsibility and for co-resident parents, responsibility also involves managerial oversight and supervision. Qualitative characteristics of father-child interactions such as warmth, affect, sensitivity, and participation during specific engagements with children are important aspects of father involvement as well. As shown in a recent meta-analysis, father involvement has the most positive effects when the father-child relationship is supportive (Amato \& Rejac, 1994). Thus, the warmth or closeness of the father-child relationship may crucially mediate the benefits of increased involvement (Lamb, 1997).

Multidimensional constructions of father involvement have not yet been integrated into a comprehensive conceptual framework. The challenge to researchers is to strike a balance between sensitivity to multiple dimensions of father involvement and explanatory parsimony. We need to ask about relations among dimensions of father involvement, and how changes to one dimension (e.g., responsibility) affect others (e.g., availability). Likewise, we must look at father involvement as it operates within a family system that gives it a particular meaning and significance (Parke \& Buriel, 1997).

Outcomes for children. The existence of complex sociocultural circumstances forces theorists to pose complex questions about the patterns of influence on child development. Which outcomes in children are most influenced by which dimensions of father involvement, at which developmental stages, and how? Preliminary answers to this multifaceted question are sometimes contradictory because of variations among studies in the ages of children and outcomes assessed, 
as well as differences in definitions of the fathers studied (Amato \& Rivera, 1999).

Fathers' emotional investment in, attachment to, and provision of resources for their children are all associated with the well-being, cognitive development, and social competence of young children even after the effects of such potentially significant confounds as family income, neonatal health, maternal involvement, and paternal age are taken into account (e.g., Amato \& Rivera, 1999; Yogman, Kindlon, \& Earls, 1995). In addition, fathers have been found to be important players in the development of children's emotional regulation and control (Gottman, Katz, \& Hooven, 1997). During middle childhood, paternal involvement in children's schooling in both single-father and two-parent families is associated with greater academic achievement and enjoyment of school by children (Nord, Brimhall, \& West, 1997). For both resident and nonresident fathers, active participation in their children's lives, rather than simply the amount of contact, appears to be formatively important (Nord et al.). In adolescence, too, stronger and closer attachments to resident biological fathers or stepfathers are associated with more desirable educational, behavioral, and emotional outcomes (Furstenberg \& Harris, 1993). High involvement and closeness between fathers and adolescents, rather than temporal involvement per se, protect adolescents from engaging in delinquent behavior and experiencing emotional distress (Harris, Furstenberg, \& Marmer, 1998). Thus, both quantity and quality of father involvement combined into the concept of "positive paternal involvement" results in positive child outcomes.

It is important to emphasize that there is no evidence linking parental involvement per se (i.e., amount) with desirable outcomes. For example, fathers who are better off financially spend less time with their children than do low-income fathers; however, their involvement is more positive (Levy-Shiff \& Israelashvili, 1988). Likewise, when fathers are pressed involuntarily into child care or parental chores because of job loss while their partners maintain employment, children do not benefit and sometimes suffer (Russell, 1983). Such fathers parent harshly (Elder, Van Nguyen, \& Caspi, 1985).

Little is known about the effects of nonresident fathers' involvement on children's development. Many nonresident fathers withdraw from their children's lives, seriously jeopardizing father-child relationships (Furstenberg \& Harris, 1993; Nord \& Zill, 1996). A review of the survey literature reveals no evidence that nonresident father involvement benefits children (Greene, Halle, LeMenestrel, \& Moore, 1998). Yet, when father involvement is measured in terms of child support payments, researchers have found beneficial effects on children (McLanahan \& Sandefur, 1994). The literature on nonresident father involvement has rarely focused on the quality of the fatherchild relationship, however. Data such as these are sorely needed and will soon be available (Cabrera, Tamis-LeMonda, Lamb, \& Boller, 1999).

Pathways of influence. Changing patterns of family organization may provide opportunities to understand how fathers positively influence the development of their infants, children, and adolescents. Both direct and indirect patterns of influence are likely to exist. A father's engagement with his child will likely exert direct influences on child development in the same way that the quality of mother-child attachment influences child development (Lamb, 1997). Paternal accessibility might likewise offer the child a sense of security and emotional support.

Children may benefit from interacting with two involved parents, and may profit from interacting with people who have different behavioral styles. Some researchers have argued that this stylistic difference is gender-based (Popenoe, 1996). Fathers' biological and socially reinforced masculine qualities predispose them to treat their children differently than do mothers. For example, fathers are more likely than mothers to encourage their children to be competitive and independent and to take risks. Yet others have challenged the universality of stylistic differences between mothers and fathers (Hewlett, 1992).

With respect to indirect effects, the benefits obtained by children with highly involved fathers may be largely attributable to the harmonious family contexts enjoyed by most of those studied (Lamb, 1986). Parents who feel good about their marital relationships, their individual goals, and their child care arrangements are in a better position to meet the challenges of parenting (Herzog, Goldberg, Michaels, \& Lamb, 1985). There is ample empirical support for the hypothesis that marital harmony is associated with quality of parent-child relationships and child adjustment (Gable, Crnic, \& Belsky, 1994), whereas marital conflict is associated with maladjustment (Cummings \& O'Reilly, 1997; Emery, 1994). Conversely, high levels of parental conflict may offset the benefits of nonresident fathers' involvement for many children (Doherty, Kouneski, \& Erickson, 1998).

The extent to which fathers meet their financial responsibilities can indirectly affect their children by influencing the economic structure of the household. We know that poverty is strongly associated with low academic achievement, psychosocial problems, delinquency, and crime (Duncan \& Brooks-Gunn, 1997). The financial support of a nonresident father can 
make a difference as to whether his child lives in poverty. Furthermore, some researchers distinguish between cooperative and noncooperative awards, reporting that voluntary child support, rather than no support or court-ordered support, may foster cognitive development because it does not adversely affect family processes (Argys, Peters, Brooks-Gunn, \& Smith, 1998). High marital conflict is linked with low quality parent-child relationships, which in turn have negative effects on children. Conversely, voluntary child support payments may enhance parentchild and mother-father relationships by increasing a father's contact with his child and diminishing conflict between parents (e.g., McLanahan, Seltzer, Hanson, \& Thomas, 1994). Less conflict between parents is associated with more agreement on how money should be spent, which leads to more resources going directly to the child (Argys \& Peters, 1996).

\section{BECOMING A FATHER}

Views about what it means to be a father and the roles of fatherhood are constructed over many years, beginning in early childhood. Boys become fathers to boys who will become fathers in the future. No researcher has described the paths that move boys to the practice of fathering, nor even constructed a unified theory explaining the complex set of developmental processes that give meaning to and shape the practice of fatherhood (Lamb, 1997; Tanfer \& Mott, 1998). Similarly, relatively little is known about factors that contribute to changes in a father's involvement in his child's life over time. We need theories that articulate relations between the timing of fatherhood in relation to its own course and the course of children's development (Neville \& Parke, 1997).

Boys becoming fathers. To date, there is little research on how role models, the informal assignment of household tasks and responsibilities, the articulation of ideas and values by adults, or formal instruction shape what fatherhood means to boys as they move toward adulthood. The available research suggests that the connections between fatherhood and childhood experiences are neither simple nor consistent across individuals. For example, fathers tend to parent more like their fathers than like their mothers (Losh-Hesselbart, 1987), but few fathers-ironically, even those who tend to take less responsibility for their children-say they learned to parent from their own fathers (Hofferth, 1999b).

More than mothers, fathers have always been afforded discretion in defining their parental roles and responsibilities, and it is thus especially important to understand the motivational bases of paternal in- volvement that are rooted in childhood. Insight into the development of gender role attitudes, sensitivity, supportiveness, accessibility, and responsibility may afford particularly useful windows on the development of fatherhood. Similarly, because fathering involves the repetitive enactment of action patterns in the context of family life, examining aspects of action patterns that seem connected to generative fathering earlier in life-such as nurturance, distance regulation, problem-solving, stress management, and displays of affection and aggression - would be informative. Fathering is also embedded in work and community contexts, so it may be worth investigating whether emerging concepts of fatherhood are connected to boys' schooling and leisure-time activities and to their involvement in religious and social organizations.

Clearly, the meaning and practices of fatherhood are related to gender identity (Daly, 1993; Lytton \& Romney, 1991; Witt, 1997) and to men's experiences with their own fathers and other kin (Cowan \& Cowan, 1987; Herzog, 1979). For example, men whose fathers were involved in raising them have been found to be more involved with their own children, to take more responsibility for them, to show more warmth, and to more closely monitor their behaviors and activities (Hofferth, 1999b). In addition, previous caretaking experience and nongender-stereotyped task assignments during childhood may increase the likelihood of father involvement during adulthood (Gerson, 1993; Pleck, 1997). Fathers with more gender-equitable attitudes tend to be more active, responsible, and warm, and to monitor their children's behavior more than do those with less gender-equitable values (Hofferth, 1998), although the impact of their involvement appears to depend on children's affective responses and social status (Parke, 1996; Pleck, 1997).

Fathers' own development. There exists a small literature on the transitions in attitudes and behaviors that fathers experience at various points in their children's lives (Bozett, 1985; Snarey, 1993). Fathers play many roles within the family and each of these roles is associated with a set of ideas, competencies, and action patterns. Information exists on the developmental course for some of the constituent components (e.g., empathy) related to certain fathering roles (Hartup \& VanLieshout, 1995; Turiel, 1997), but almost nothing is known about how, and under what circumstances, these components become integrated and enacted over the life course.

We also know little about how men learn to be fathers (Daly 1993; Tanfer \& Mott, 1998). In 1997, only about $11 \%$ of fathers in two-parent households had taken a formal parenting class although those who did tended to be more involved in their children's 
lives (Hofferth, 1999b). Cultural and social changes have weakened the connection between masculinity and the expectation of responsible fatherhood (Marsiglio, 1998). These changing circumstances have led to a bifurcation of the adult male population into those who assume care of their children and those who do not (Furstenberg, 1988). While some argue that fatherhood has ceased to be a normative expectation and has become a voluntary commitment, others argue that effective fatherhood is an essential quality of masculinity (Blankenhorn, 1995). Indeed, this debate will become more complex as new technologies, that will be further developed in the new century, continue to reshape the way men and women think and experience their procreative roles (Marsiglio, 1998).

Research on the development of fatherhood is complicated by the fact that there is no singular set of developmental endpoints or tasks that define competent, supportive fathering for all men. This is particularly true where fathering outside the traditional family model is concerned. In fact, the majority of men assume and enact fathering roles outside of, or in addition to, the traditional circumstance, whether as step-fathers, nonresidential fathers, single fathers or fathers of adult children, even though highly involved coparenting, responsible fathering, and generative fathering have emerged as idealized, generic goals for male parenting (Doherty, et al., 1998; Lamb, in press; Snarey, 1993). Moreover, traditional and generative models of male parenting do not consider the role that the child's developmental stage plays in the development of fatherhood. Men do not father in a social vacuum; we need to consider the bidirectionality of the father-child relationship in determining the development of fatherhood. As the child grows and develops, displaying a new set of developmental assets (as well as liabilities), the father is also developing and changing.

The timing of fatherhood. The timing of fatherhood often determines the paths that fathering takes, as well as the management of related developmental tasks. Dramatic changes in family life over the last half-century have diversified the life course options for men to the extent that there no longer exists a tight link between the timing of employment and the timing of parenting in men's lives. Nor is it certain whether, or for how long, men will reside with their children. The timing of other life experiences, such as the initiation of dating, birth of a sibling, and divorce, may help determine both the pathway to fatherhood and the paths that men take upon becoming fathers (Lerman, 1993).

The timing of fatherhood sets men on different life course trajectories depending on their own developmental stage. Compared to the transition to fatherhood for adult males, the transition to parenthood for adolescent males is more likely either to constitute a "crisis" or to signify little beyond the event itself (Jordan, 1997; Marsiglio, 1987). When young men become fathers, it is often unintentional, whereas for older men, having a child is most often an intended event. Although we know little about the relationship between men's intentions toward fertility and paternal involvement, the existing evidence suggests that a father's positive parenting may be strongly associated with whether the pregnancy was intended (Brown \& Eisenberg, 1995). Unwanted and mistimed childbearing in two-parent households has been found to exert long-term effects on children's self-esteem, suggesting that parents may be less involved and supportive with children whose birth was unintended (Axinn, Barber, \& Thornton, 1998). These findings, however, may vary as a function of psychological and economic resources, as well as social support. Certainly, adolescent parenting seems to be associated with higher risk for children, whereas older men seem to deal with parenthood better (Coley \& Chase-Lansdale, 1998).

\section{CONCLUSION}

As we approach the twenty-first century, the structures and functions of family life are rapidly changing in the face of four prominent social trends: increased female employment, increased father absence, increased father involvement, and increased cultural diversity. These changes have led to different family structures as well as to different expectations and beliefs about the roles of fathers. Participation of women in the labor force will likely continue to rise during the next century. The extent of father involvement and responsibility in child care is also likely to increase. As men become integral to domestic and child rearing activities, they will take more responsibility for the organization and planning of their children's lives.

Unfortunately, not all children will grow up having meaningful contacts with their fathers, as singleparent households continue to rise. Child support payments will benefit children most when fathers want to support their children and when there is harmony between parents. Lessons learned from ongoing welfare studies will shed light on the dynamic intersection between employment, economic well-being, and family well-being.

Will the gap between involved and uninvolved fathers continue to widen? It appears that the answer is yes, at least for the immediate future. It is not clear whether our economy can absorb the least educated and those with less social and human capital. Lack of economic resources will seriously undermine men's roles as providers and might increase marital conflict. 
These men will have to overcome tremendous adversities to provide for their children. If, despite their best intentions (McLanahan, 1999), they are unable to meet these challenges, their absence from their families will have dire consequences for their children's development. This will be especially true for children who lack the necessary social and family support to moderate the effects of father absence.

Whether men who are unable to provide for their families or who are in conflict with their spouses can effectively negotiate their roles as fathers will depend on how we (researchers, policymakers, practitioners) integrate our resources to institute policies and programs that aim at helping families help themselves. Moreover, we need to be sensitive to circumstances in which father involvement is not in the best interest of the child. In the context of domestic and community violence, for example, successful services for families can play a key role in fostering positive paternal involvement.

Perhaps now more than ever we appreciate the diversity of fathers, including cultural and ethnic variations in the meaning of fatherhood, roles of fathers, and their influences on children. No single definition of "successful fatherhood" and no ideal "father's role" can claim universal acceptance or empirical support. Rather, fathers' expectations about what they should do, what they actually do, and their effects on children must be viewed within the contexts of family, community, culture, and current history. These ethnic and culturally diverse conceptions of fatherhood have differential effects on children's outcomes and might work through different pathways. Such research is critical for program design and implementation.

Although we have placed emphasis in this essay on fathers and their children, the social and economic conditions that are reshaping the roles and behaviors of fathers are recasting the lives of mothers as well. What once seemed a natural pattern-a parenting model in which fathers were viewed as "helpers" to mothers-is now yielding to new cultural ideals, such as coparenting. Changes in the responsibilities of men and women are creating a new set of expectations, beliefs, and attitudes about what men and women should do in the context of family. The ideal of coparent represents an important shift because it obliterates a "gender division of labor in domestic and breadwinning responsibilities" (Pleck, 1997, p. 48). Coparents must share tasks and responsibilities equally, and their roles are genderfree. Consequently, mothers' role as gatekeeper is likely to diminish. This intergenerational legacy of coparenting embodies an image that is beginning to take shape in the collective social consciousness.

As mothers shift from being primary caregivers to being coparents, developmental theories that place mothers as the central influences on children's lives must be revised. Women who as children experienced nurturing from and involvement with their fathers will develop different expectations about whom to marry and whether and how they and their partners will share the tasks of parenting. The next generation of boys and girls will be more likely to experience mothers who work full time outside the home and fathers who cook dinner. Consequently, children are being reared with different expectations about their future roles and those of their future partners.

The four social trends outlined in this essay foretell even greater adjustments in family life in the future. This greater complexity is likely to alter social institutions and the policies that affect parents and children. For example, employers are increasingly forced to recognize the parental responsibilities of both mothers and fathers, perhaps by offering more flexible work schedules and enhanced paternity leave. Changes in the roles of fathers, mothers, and families will reverberate in many institutional settings, including work, day-care, and schools, ultimately exerting major direct and indirect effects on children's outcomes. As we enter the new millennium, a serious challenge to social scientists is to capture these changes and integrate them into theories, methodological approaches, policies, and practices that aim to explain and predict children's developmental trajectories.

\section{ACKNOWLEDGMENTS}

We wish to acknowledge Jacqueline Shannon, Nancy Thomas, Lori Roggman, Jeff Evans, Chris Bachrach, and the Early Head Start (EHS) Father Studies Work Group. The EHS Father Studies Work Group members represent the national EHS evaluation contractor (Mathematica Policy Research and Columbia University); the funding agencies (Administration on Children, Youth and Families, National Institute of Child Health and Human Development, Office of the Assistant Secretary for Planning and Evaluation in DHHS, and the Ford Foundation); the local research universities participating in the EHS Research Consortium; and program directors from the EHS programs participating in the national evaluation. We would also like to thank Judi Smetana and two anonymous reviewers for their very helpful and insightful comments on this manuscript.

\section{ADDRESSES AND AFFILIATIONS}

Corresponding author: Natasha Cabrera, National Institute of Child Health and Human Development, 
Center for Population Research, DBSB, 6100 Executive Blvd., Room 3B07, Bethesda, MD 20892-7510; e-mail: cabreran@exchange.nih.gov. Michael E. Lamb is also at the National Institute of Child Health and Human Development; Catherine S. Tamis-LeMonda is at New York University, New York; Robert H. Bradley is at the University of Arkansas at Little Rock, AR; and Sandra Hofferth is at the Institute for Social Research at the University of Michigan, Ann Arbor, MI.

\section{REFERENCES}

Amato, P. R. (1993). Children's adjustment to divorce: Theories, hypotheses, and empirical support. Journal of Marriage and the Family, 55, 23-38.

Amato, P. R., \& Rejac, S. J. (1994). Contact with non-resident parents, interparental conflict, and children's behavior. Journal of Family Issues, 15, 191-207.

Amato, P. R., \& Rivera, F. (1999). Paternal involvement and children's behavior problems. Journal of Marriage and Family, 61, 375-384.

Argys, L. M., \& Peters, H. E. (1996). Can adequate child support be legislated? A theoretical model of responses to child support guidelines and enforcement efforts. Mimeographed document, Cornell University, Department of Policy Analysis and Management.

Argys, L. M., Peters, H. E., Brooks-Gunn, J., \& Smith, J. R. (1998). The impact of child support dollars on cognitive outcomes. Demography, 35(2), 159-173.

Axinn, W. G., Barber, J. S., \& Thornton, A. (1998). The longterm impact of parents' childbearing decisions on children's self-esteem. Demography, 35, 435-443.

Blankenhorn, D. (1995). Fatherless America: Confronting our most urgent social problem. New York: Basic Books.

Bozett, F. W. (1985). Male development and fathering throughout the life cycle. American Behavioral Scientist, $29,41-54$.

Bozett, F. W., \& Hanson, S. M. H. (Eds.). (1991). Fatherhood and families in cultural context. New York: Springer.

Brayfield, A. (1995). Juggling jobs and kids: The impact of employment schedules on fathers' caring for children. Journal of Marriage and the Family, 57, 321-332.

Brown, S. S., \& Eisenberg, L. (Eds.). (1995). The best intentions. Washington, DC: National Academy Press.

Bumpass, L. L., Sweet, J. A., \& Castro-Martin, T. C. (1990). Changing pattern of marriage. Journal of Marriage and Family, 52, 747-756.

Cabrera, N., Tamis-Lemonda, C., Lamb, M., \& Boller, K. (in press). Measuring father involvement in the Early Head Start Evaluation: A multidimensional conceptualization. National Conference on Health Statistics, Washington, DC.

Casper, L. M. (1997). My daddy takes care of me! Fathers as care providers. Current population reports, 70-59. Washington, DC: U.S. Bureau of the Census.

Casper, L. M., \& O'Connell, M. (1998). Work, income, the economy, and married fathers as child care providers. Demography, 35(2), 243-250.
Coley, R. L., \& Chase-Lansdale, P. L. (1998). Adolescent pregnancy and parenthood. American Psychologist, 53, 152-166.

Cowan, C., \& Cowan, P. (1987). Men's involvement in parenthood: Identifying the antecedents and understanding the barriers. In P. Berman, P. Pedersen, \& F. Pedersen (Eds.), Men's transitions to parenthood: Longitudinal studies of early family experience (pp. 145-174). Hillsdale, NJ: Lawrence-Erlbaum.

Cummings, E. M., \& O'Reilly, A. W. (1997). Fathers in family context: Effects of marital quality on child adjustment. In M. E. Lamb (Ed.), The role of the father in child development (pp. 49-65). New York: Wiley.

Daly, K. (1993). Reshaping fatherhood: Finding the models. Journal of Family Issues, 14, 510-530.

Doherty, W. J., Kouneski, E. F., \& Erickson, M. F. (1998). Responsible fathering: An overview and conceptual framework. Journal of Marriage and the Family, 60, 277-292.

Duncan, G., \& Brooks-Gunn, J. (1997). Consequences of growing up poor. New York: Russell Sage.

Elder, G., Van Nguyen, T., \& Caspi, A. (1985). Linking family hardship to children's lives. Child Development, 56, 361-375.

Emery, R. E. (1994). Renegotiating family relationships: Divorce, child custody and mediation. New York: Guilford.

Engle, P. L., \& Breaux, C. (1998). Fathers' involvement with children: Perspectives from developing countries. Social policy report, Society for Research in Child Development, XII(1), 2-21.

Federal Interagency Forum on Child and Family Statistics. (1998). Nurturing fatherhood: Improving data and research on male fertility, family formation, and fatherhood. Washington, DC: U.S. Government Printing Office.

Fincham, F. (1998). Child development and marital relations. Child Development, 69, 543-574.

Furstenberg, F. F. (1988). Good dads-bad dads: The two faces of fatherhood. In A. J. Cherlin (Ed.), The changing American family and public policy (pp. 193-218). Washington, DC: Urban Institute Press.

Furstenberg, F. F., Jr., \& Harris, K. (1993). When and why fathers matter: Impacts of father involvement on the children of adolescent mothers. In R. Lerman \& T. Ooms (Eds.), Young unwed fathers: Changing roles and emerging policies (pp. 150-176). Philadelphia: Temple University Press.

Gable, S., Crnic, K., \& Belsky, J. (1994). Coparenting within the family system: Influences on children's development. Family Relations, 43, 380-386.

Gerson, K. (1993). No man's land: Men's changing commitments to family and work. New York: Basic Books.

Gottman, J. M., Katz, L. F., \& Hooven, C. (1997). Metaemotion. Hillsdale, NJ: Erlbaum.

Greene, A. D., Halle, T. G., Le Menestrel, S., \& Moore, K. A. (1998). Father involvement in young children's lives: Recommendations for a fatherhood module for the ECLS-B. Paper prepared for the National Center for Education Statistics by Child Trends, Inc., Washington, DC.

Harris, K., Furstenberg, F. F., Jr., \& Marmer, J. K. (1998). Paternal involvement with adolescentsin intact families: The influence of fathers over the life course. Demography, 35(2), 201-216. 
Hartup, W. W., \& vanLieshout, C. F. M. (1995). Personality development in social context. Annual Review of Psychology, 46, 655-687.

Hernandez, Donald J. (1993). America's children: Resources from family, government and the economy. New York: Russell Sage.

Herzog, J. M (1979). Patterns of expectant fatherhood. Dialogue: Journal of Psychoanalytic Perspectives, 30, 55-67.

Herzog, J. M., Goldberg, W. A., Michaels, B. Y., \& Lamb, M. E. (1985). Husbands' and wives' adjustment to pregnancy and first parenthood. Journal of Family Issues, 6, 483-503.

Hetherington, E. M., Cox, M., \& Cox, R. (1982). Effects of divorce on parents and children. In M. Lamb (Ed.), Nontraditional families (pp. 233-233). Hillsdale, NJ: Erlbaum.

Hetherington, E. M., \& Henderson, S. H. (1997). Fathers in stepfamilies. In M. E. Lamb (Ed.), The role of the father in child development (3rd ed., pp. 212-226). New York: Wiley.

Hetherington, E. M., \& Stanley-Hagan, M. (1986). Divorced fathers: Stress, coping, and adjustment. In M. E. Lamb (Ed.), The father's role: Applied perspectives (pp. 103-134). New York: Wiley.

Hewlett, B. S. (1992). Husband-wife reciprocity and the father-infant relationship among Aka pygmies. In B. S. Hewlett (Ed.), Father-child relations: Cultural and biosocial contexts (pp. 153-176). New York: de Gruyter.

Hofferth, S. (1996). Child care in the United States today. In The future of children: Financing child care, 6(2), 41-61. California: Center for the Future of Children, The David and Lucille Packard Foundation.

Hofferth, S. (1998). Healthy environments, healthy children: Children in families. Ann Arbor, MI Institute for Social Research, University of Michigan.

Hofferth, S. (1999a). Public assistance receipt of Mexicanand Cuban-American children in native and immigrant families. In D. Hernandez (Ed.), Children of immigrants: Health, adjustment, and public assistance. Washington, DC: National Academy Press.

Hofferth, S. (1999b, April). Race/ethnic differences in father involvement with young children: A conceptual framework and empirical test in two-parent families. Paper presented at the Urban Seminar on Fatherhood, Harvard University, Cambridge, MA.

Jordan, W. J. (1997). Role transitions: A review of the literature. Unpublished manuscript, National Center on Fathers and Families, University of Pennsylvania, Philadelphia.

Lamb, M. E. (Ed.). (1986). The father's role: Applied perspectives. New York: Wiley.

Lamb, M. (Ed.). (1997). The role of the father in child development (3rd ed.). New York: Wiley.

Lamb, M. E. (Ed.). (1999). Parenting and child development in nontraditional families. Mahwah, NJ: Erlbaum.

Lamb, M. E. (in press). Research on father involvement. An historical overview. Marriage and Family Review.

Lamb, M. E., Pleck, J. H., Charnov, E., \& Levine, J. A. (1985). Paternal behavior in humans. American Psychologist, 25, 883-894.

Lamb, M. E., Pleck, J. H., Charnov, E. L., \& Levine, J. A. (1987). A biosocial perspective on paternal behavior and involvement. In J. B. Lancaster, J. Altman, A. S. Rossi, \& L. R. Sherroa (Eds.), Parenting across the lifespan: Biosocial dimensions (pp. 111-142). New York: Aldine de Gruyter.

LaRossa, R. (1997). The modernization of fatherhood: A social and political history. Chicago: University of Chicago Press.

Lerman, R. I. (1993). A national profile of young unwed fathers. In R. I. Lerman \& T. J. Ooms (Eds.), Young unwed fathers: Changing roles and emerging policies (pp. 27-51). Philadelphia: Temple University Press.

Levy-Shiff, R., \& Israelashvili, R. (1988). Antecedents of fathering: Some further exploration. Developmental Psychology, 24, 434-440.

Losh-Hasselbart, S. (1987). The development of gender roles. In M. B. Sussman \& S. Steinmetz (Eds.), Handbook of marriage and the family (pp. 535-563). New York: Plenum.

Lytton, H., \& Romney, D. M. (1991). Parents' differential socialization of boys and girls: A meta-analysis. Psychological Bulletin, 109, 267-296.

Marsiglio, W. (1987). Adolescent fathers in the United States: Their initial living arrangements, marital experience and education outcomes. Family Planning Perspectives, 12, 240-251.

Marsiglio, W. (1998). Procreative man. New York: New York University Press.

McLanahan, S. S. (1999). Testimony of Sara McLanahan before the Subcommittee on Human Resources, U.S. House of Representatives, Committee on Ways and Means, April 27.

McLanahan, S. S., \& Sandefur, G. (1994). Growing up with a single parent: What hurts, what helps. Cambridge, MA: Harvard University Press.

McLanahan, S. S., Seltzer, J. A., Hanson, T. L., \& Thomas, E. (1994). Child support enforcement and child well-being: Greater security or greater conflicts. In I. Garfinkel, S. S. McLanahan, \& P. K. Robins (Eds.), Child support and child well-being (pp. 239-254). Washington, DC: Urban Institute Press.

McLoyd, V. (1998). Socioeconomic disadvantage and child development. American Psychologist, 53, 185-204.

Mirande, A. (1988). Chicano fathers: Traditional perceptions and current realities. In P. Bronstein \& C. P. Cowan (Eds.), Fatherhood today: Men's changing role in the family (pp. 93-106). New York: Wiley.

Neville, B., \& Parke, R. (1997). Waiting for paternity: Interpersonal and contextual implications of the timing of fatherhood. Sex Roles, 37, 1-12.

Nord, C., Brimhall, D. A., \& West, J. (1997). Fathers' involvement in their children's schools. Washington, DC: Office of Educational Research and Improvement, U.S. Department of Education.

Nord, C. W., \& Zill, N. (1996). Non-custodial parents' participation in their children's lives: Evidence from the Survey of Income $\mathcal{E}$ Program Participation, 2 Vols. Final report prepared for the office of the Assistant Secretary of Planning and Evaluation, U.S. Department of Health \& Human Services.

Palkovitz, R. (1997). Reconstructing involvement: Expanding conceptualizations of men's caring in contemporary families. In A. J. Hawkins \& D. C. Dollahite (Eds.), Gen- 
erative fathering: Beyond deficit perspectives. Thousand Oaks, CA: Sage.

Parke, R. (1996). Fatherhood. Cambridge, MA: Harvard University Press.

Parke, R. D., \& Buriel, R. (1997). Socialization in the family: Ethnic and ecological perspectives. In N. Eisenberg (Ed.), W. Damon (Series Ed.), Handook of child psychology: Vol. 3. Social, emotional, and personality development (5th ed., pp. 463-552). New York: Wiley.

Pearson, J. P., \& Thoennes, N. (1988). Supporting children after divorce: The influence of custody on support levels and payments. Family Law Quarterly, 22, 319-339.

Phillips, D., \& Cabrera, N. (1996). Beyond the blueprint: Directions for research on Head Start's families. Board on Children, Youth, and Families. Washington, DC: National Academy Press.

Pleck, E. H. (1997). Paternal involvement: Levels, sources, and consequences. In M. E. Lamb (Ed.), The role of the father in child development (3rd ed., pp. 66-103). New York: Wiley.

Pleck, E. H., \& Pleck, J. H. (1997). Fatherhood ideals in the United States: Historical dimensions. In M. E. Lamb (Ed.), The role of the father in child development (3rd ed., pp. 33-48). New York: Wiley.

Popenoe, D. (1996). Life without father. New York: Free Press.

Presser, H. (1995). Job, family, and gender: Determinants of non-standard work schedules among employed Americans in 1991. Demography, 32, 577-598.

Pruett, K. (1987). The nurturing father. New York: Warner Books.

Russell, G. (1983). The changing roles of fathers. St. Lucia, Queensland: University of Queensland Press.

Seltzer, J. A. (1994). Intergenerational ties in adulthood and childhood experience. In A. Booth \& J. Dunn (Eds.), Stepfamilies: Who benefits? Who does not? (pp. 89-96). Hillsdale, NJ: Erlbaum.

Snarey, J. (1993). How fathers care for the next generation. Cambridge, MA: Harvard University Press.

Spain, D., \& Bianchi, S. M. (1996). Balancing act: Motherhood, marriage, and employment among American women. New York: Russell Sage Foundation.
Tamis-LeMonda, C., \& Cabrera, N. (1999). Perspectives on father involvement: Research and policy. Social Policy Report, Society for Research in Child Development.

Tanfer, K., \& Mott, F. (1998). The meaning of fatherhood for men. In Nurturing fatherhood: Improving data and research on male fertility, family formation and fatherhood (pp. 249293). Washington, DC: Federal Interagency Forum on Child and Family Statistics.

Thompson, R. A. (1986). Fathers and the child's best interests: Judicial decision-making in custody disputes. In M. E. Lamb (Ed.), The father's role: Applied perspectives. New York: Wiley.

Turiel, E. (1997). The development of morality. In N. Eisenberg (Ed.), W. Damon (Series Ed.), Handbook of child psychology: Vol. 3. Social, emotional, and personality development (5th ed., pp. 863-932). New York: Wiley.

U.S. Bureau of the Census. (1998). Statistical abstract of the United States 1998. Washington, DC: U.S. Department of Commerce.

U.S. Bureau of the Census. (1999). Current population reports: Growth in single fathers outpaces growth in single mothers. (Series P20, No. 1344). Washington, DC: U.S. Government Printing Office.

U. S. Department of Labor, Bureau of Labor Statistics. (1986). Labor force participation rates of married women, husband present, by presence and age of own children, 1950-1984. Unpublished tables.

U. S. Department of Labor, Bureau of Labor Statistics. (1997). Marital and family characteristics of the labor force from the March 1997 Current population survey. Unpublished statistics.

Witt, S. D. (1997). Parental influences on children's socialization to gender roles. Adolescence, 32, 253-258.

Yeung, W. J., Sandberg, J. F., Davis-Kean, P., \& Hofferth, S. L. (1998, April). Children's time with fathers in intact families. Paper presented at the annual meeting of the Population Association of America.

Yogman, M. W., Kindlon, D., \& Earls, F. (1995). Father involvement and cognitive/behavioral outcomes of preterm infants. Journal of the American Academy of Child and Adolescent Psychiatry, 343, 58-66. 